\title{
Gambaran Hasil Pemeriksaan Laringoskopi Fiber Optik pada Pasien Rawat Inap di RSUP. Prof. Dr. R. D. Kandou Periode 2014 -2017
}

\author{
${ }^{1}$ Yosua K. G. Monintja \\ ${ }^{2}$ Steward K. Mengko \\ ${ }^{2}$ Olivia C. P. Pelealu
}

\author{
${ }^{1}$ Program Studi Pendidikan Dokter Fakultas Kedokteran Universitas Sam Ratulangi Manado \\ ${ }^{2}$ Bagian Ilmu Kesehatan Telinga Hidung Tenggorokan Kepala Leher Fakultas Kedokteran \\ Universitas Sam Ratulangi Manado \\ Email: yosuamonintja@gmail.com
}

\begin{abstract}
Flexible fiber-optic laryngoscopy is one of the most common tool to identify abnormalities in larynx and its surrounding structures, biopsy, or to find abnormal tissues, such as polyps on the larynx. One of the advantages of this tool is the presence of a flexible camera that can be manipulated precisely so that it can show the whole vocal cord movement. In addition, the endoscope used in this procedure is made of thin and flexible fiber optic cable, therefore, the patient only experiences slight discomfort when the laryngoscope is inserted that does not require a long time. This study was aimed to describe the results of fiber-optic laryngoscopy (FOL) in hospitalized patients admitted to Prof. Dr. R. D. Kandou Hospital Manado from 2014 to 2017. This was a descriptive retrospective study with a cross sectional design. Based on medical records, respondents were all inpatients who had the results of FOL examination at the Department of ENT-Head and Neck Surgery Prof. Dr. R. D. Kandou Hospital Manado. From 11 samples, the most common pathological features were arytenoid edema (35.71\%) and hyperemic (28.58\%), with dysphonia (80\%) as the most frequent indication for FOL. Conclusion: The most frequent indication of FOL was dysphonia and the most common pathological abnormalities found were edema and hyperemic of arytenoid.
\end{abstract}

Keywords: fiber optic laryngoscopy (FOL)

\begin{abstract}
Abstrak: Flexible fiber-optic laryngoscopy ialah pemeriksaan yang paling umum untuk mengetahui kelainan laring dan sekitarnya, biopsi, atau melihat jaringan abnormal seperti polip pada bagian laring. Salah satu keuntungan dari alat ini ialah kamera fleksibel yang dapat dimanipulasi secara tepat sehingga dapat menunjukkan gerakan pita suara secara penuh. Selain itu, endoskopi yang digunakan dalam prosedur ini terbuat dari kabel fiber optik yang tipis dan fleksibel, pasien hanya mengalami sedikit tidak nyaman saat alat dimasukkan dan tidak memerlukan waktu yang lama. Penelitian ini bertujuan untuk mengetahui gambaran hasil pemeriksaan fiber-optic laryngoscopy (FOL) pada pasien rawat inap di RSUP Prof. Dr. R. D. Kandou Manado dari tahun 2014 hingga 2017. Jenis penelitian ialah deskriptif retrospektif dengan desain potong lintang. Responden ialah seluruh pasien rawat inap yang memiliki hasil pemeriksaan FOL yang tercantum dalam rekam medik di KSM THT-KL RSUP Prof. Dr. R. D. Kandou Manado. Hasil penelitian memperlihatkan dari 11 sampel didapatkan gambaran patologik yang paling sering ialah aritenoid yang edema $(35,71 \%)$ dan hiperemis $(28,58 \%)$ dengan disfonia (80\%) sebagai indikasi paling sering untuk pemeriksaan. Simpulan: Pada pemeriksaan FOL, indikasi tersering ialah disfonia dan gambaran patologik tersering didapatkan ialah edema dan hiperemis aritenoid.
\end{abstract}

Kata kunci: laringoskopi fiber optic (FOL) 
Laringoskopi merupakan pemeriksaan laring yang digunakan untuk menginspeksi nasofaring, hipofaring, dan glotis. Laringoskopi dapat digunakan untuk intubasi trakea saat anastesi atau resusitasi jantung paru serta prosedur-prosedur operatif di bagian laring dan saluran napas atas. ${ }^{1}$

Laringoskopi direk (direct laryngoscopy) merupakan pemeriksaan laring secara langsung dengan menggunakan kabel serat optik dan laringoskopi kaku. Berbeda dengan gambaran yang dihasilkan kaca pada laringoskopi indirek, pada laringoskopi direk dapat terlihat laring secara langsung untuk mendeteksi adanya tumor, benda asing, kerusakan saraf atau struktur lain maupun kelainan-kelainan lain. Terdapat dua cara pemeriksaan laringoskopi direk (laryngoscopy direct) yang saat ini dilakukan untuk memeriksa laring, yaitu: 1) menggunakan alat laringoskop kaku yang dimasukkan langsung dari mulut hingga ke dalam laring; 2) menggunakan kabel serat optik yang lentur (fleksibel) yang dimasukkan melalui hidung dan diteruskan hingga masuk ke dalam tenggorokan dan disebut flexible fiber-optic laryngoscopy (FFOL). ${ }^{1}$

Flexible fiber-optic laryngoscopy merupakan pemeriksaan yang paling umum digunakan untuk melihat tenggorokan dan struktur sekitarnya. Pemeriksaan ini dilakukan untuk mengetahui kelainan, biopsi, atau melihat adanya jaringan abnormal, seperti polip pada bagian laring. Laringoskopi fiber optik fleksibel dapat menunjukkan bagian-bagian seperti nasofaring, orofaring, hipofaring dan laring. Salah satu keuntungan dari jenis laringoskopi ini ialah kamera yang fleksibel dapat dimanipulasi secara tepat sehingga dapat menunjukkan gerakan pita suara secara penuh. Selain itu, endoskopi yang digunakan dalam prosedur ini terbuat dari kabel fiber optik yang tipis dan fleksibel sehingga pasien hanya mengalami sedikit tidak nyaman saat alat dimasukkan dan tidak memerlukan waktu yang lama. ${ }^{2}$

Di Rumah Sakit Cipto Mangunkusumo (RSCM) tahun 2014-2015, laringoskopi fleksibel digunakan pada 32 pasien, terdiri dari 20 pasien laki-laki dan 12 pasien perempuan. Keluhan terbanyak ialah disfagia (18 pasien), globus atau refluks (12 pasien), dan dengan diagnosis terbanyak akalasia esofagus (7 pasien). ${ }^{3}$ Pada RSUD Dr. Soetomo pada tahun 2009-2012, didapatkan 114 pasien yang menggunakan pemeriksaan endoskopi fleksibel untuk kepentingan diagnostik. ${ }^{4}$ Data dari RSCM, 72 pasien anak-anak dengan kecurigaan disfagia, terdiri dari 47 pasien disfagia neurogenik, 7 pasien disfagia mekanik, dan 18 pasien kesulitan makan. ${ }^{5}$ Data di RSUP. Prof. Dr. R. D. Kandou Manado periode Januari 2016-Agustus 2016 memperlihatkan endoskopi fleksibel digunakan di Bagian Penyakit Dalam pada 59 orang yang mayoritas merupakan pasien laki-laki (30 orang). ${ }^{6}$

Sampai saat ini, belum ada data yang pasti tentang pemeriksaan FOL di Bagian/ KSM THT-KL RSUP Prof. Dr. R. D. Kandou Manado. Penelitian ini bertujuan untuk mengetahui gambaran hasil pemeriksaan fiber-optic laryngoscopy (FOL) pada pasien rawat inap di RSUP Prof. Dr. R. D. Kandou Manado dari tahun 2014 hingga 2017.

\section{METODE PENELITIAN}

Jenis penelitian ini ialah deskriptif dengan desain potong lintang. Teknik pengambilan sampel pada penelitian ini menggunakan total sampling. Sampel penelitian ini ialah pasien rawat inap yang memiliki hasil pemeriksaan FOL di KSM THT-KL Fakultas Kedokteran Universitas Sam Ratulangi/RSUP Prof. Dr. R. D. Kandou. Data kemudian diolah dengan Microsoft Excell 2013 dan disajikan dalam bentuk tabel distribusi dan frekuensi.

\section{HASIL PENELITIAN}

Berdasarkan data rekam medik RSUP Prof. Dr. R. D. Kandou Manado periode 2014-2017, didapatkan 28 sampel yang menggunakan pemeriksaan FOL. Sebanyak 13 sampel yang dieksklusi akibat data rekam medik yang tidak lengkap sehingga didapatkan sebanyak 15 sampel yang memenuhi kriterian inklusi.

Tabel 1 memperihatkan bahwa berda- 
sarkan data rekam medik dari 15 pasien didapatkan pemeriksaan FOL lebih sering dilakukan pada pasien laki-laki dengan jumlah 9 sampel (60\%) sedangkan pasien perempuan sebanyak 6 sampel (40\%). Dari rentang usia 9-67 tahun didapatkan rerata usia pasien $43 \pm 16,22$ tahun. Pemeriksaan FOL kebanyakan dilakukan pada pasien dengan keluhan disfonia yaitu sebanyak 12 sampel $(80 \%)$ sedangkan pada pasien batuk darah terdapat 1 sampel (10\%). Selain itu, disfagia dengan jumlah 1 sampel (10\%). Dari penelitian ini juga didapatkan bahwa dari 15 pasien yang menggunakan FOL, 9 sampel $(60 \%)$ didiagnosis utama disfonia akibat obstruksi, kanker laring sebanyak 3 sampel (20\%), akibat laringitis akut 2 sampel $(13,33 \%)$, dan yang terakhir akibat hemoptisis sebanyak 1 sampel $(6,67 \%)$ (Tabel 1).

Tabel 1. Demografi sampel penelitian

\begin{tabular}{lcc}
\hline & Jumlah & $\begin{array}{c}\text { Persentase } \\
(\%)\end{array}$ \\
\hline Rerata usia (tahun) & $43 \pm 16.22$ & \\
Jenis kelamin & & \\
$\quad$ Laki-laki & 9 & 60 \\
$\quad$ Perempuan & 6 & 40 \\
Keluhan & & \\
$\quad$ Disfonia & 12 & 80 \\
Batuk darah & 1 & 10 \\
$\quad$ Disfagia dan disfonia & 1 & 10 \\
Diagnosis utama & & \\
Ca laring & 3 & 20 \\
$\quad$ Disfonia & 9 & 60 \\
Laringitis akut & 2 & 13,33 \\
Hemoptisis & 1 & 6,67 \\
\hline
\end{tabular}

Berdasarkan hasil penelitian, dari 15 sampel, terdapat 1 sampel yang memiliki hasil pemeriksaan FOL tidak dapat dievaluasi. Tabel 2 memperlihatkan pada 14 sampel lainnya didapatkan gambaran kavum nasi normal pada semua pasien. Didapatkan aritenoid yang edema pada 5 sampel $(35,71 \%)$ dan hiperemis sebanyak 4 sampel $(28,58 \%)$. Juga didapatkan gambaran korda vokalis yang lapang sebanyak 12 sampel $(85,72 \%)$, menebal 1 sampel $(7,14 \%)$. Terdapat 1 sampel $(7,14 \%)$ yang sulit dievaluasi. Massa pada korda vokalis tidak ditemukan. Gambaran gerakan korda vokalis mendapatkan 13 sampel $(92,86 \%)$ dengan gerakan normal dan 1 sampel $(7,14 \%)$ dengan paresis unilateral. Juga didapatkan semua sampel memiliki celah rima glotis dan epiglotis yang normal. Gambaran tonsil menunjukkan 13 sampel $(92,86 \%)$ yang normal dan 1 sampel $(7,14 \%)$ yang tidak normal. Untuk gam- baran hasil pemeriksaan orofaring terdapat 13 sampel $(92,86 \%)$ yang lapang, dan 1 sampel $(7,14 \%)$ yang hiperemis.

\section{BAHASAN}

Penelitian ini bertujuan untuk mengetahui gambaran hasil pemeriksaan FOL pada pasien rawat inap. Jenis penelitian ini ialah deskriptif retrospektif dengan menggunakan data dari rekam medik.

FOL merupakan salah satu alat yang penting untuk membantu diagnosis dan terapetik. Alat ini sangat mudah digunakan, tidak membutuhkan biaya yang besar dan hanya membutuhkan tindakan invasif yang minimal untuk membantu menegakkan diagnosis, namun perannya sebagai alat terapetik masih di selidiki. ${ }^{7,8}$

Dari penelitian ini didapatkan bahwa rerata usia pasien yang menggunakan pemeriksaan FOL ialah $43 \pm 16,22$ tahun dengan usia terbanyak diatas 40 tahun. 
Tabel 2. Gambaran hasil pemeriksaan FOL

\begin{tabular}{lcc}
\hline & Jumlah & $\begin{array}{c}\text { Present } \\
\text { ase }(\%)\end{array}$ \\
\hline Cavum nasi normal & 10 & 100 \\
Aritenoid & & \\
$\quad$ Normal & 5 & 35,71 \\
Edema & 5 & 35,71 \\
$\quad$ Hiperemis & 4 & 28,58 \\
Korda vokalis & & \\
$\quad$ Lapang & 12 & 85,72 \\
$\quad$ Menebal & 1 & 7,14 \\
$\quad$ Sulit dievaluasi & 1 & 7,14 \\
Massa & 0 & 0 \\
Gerak & & \\
$\quad$ Normal & 13 & 92,86 \\
$\quad$ Paresis & & \\
$\quad$ Unilateral & 1 & 7,14 \\
$\quad$ Bilateral & 0 & 0 \\
Celah rima glotis & & \\
$\quad$ Normal & 14 & 100 \\
Tonsil & & \\
$\quad$ Lapang & 13 & 92,86 \\
$\quad$ Tidak normal & 1 & 7,14 \\
Epiglotis & & \\
$\quad$ Normal & 14 & 100 \\
Orofaring & & \\
$\quad$ Lapang & 13 & 92,86 \\
Hiperemis & 1 & 7,14 \\
\hline
\end{tabular}

Hasil penelitian ini sejalan dengan penelitian Wilkins et $\mathrm{al}^{9}$ yang mendapatkan rerata usia pasien sebesar 51,3 $\pm 14,6$ tahun. ${ }^{9}$

Dari data hasil penelitian didapatkan bahwa jenis kelamin terbanyak ialah lakilaki (60\%). Hasil penelitian ini selaras dengan yang didapatkan oleh Iqbal et $\mathrm{al}^{7}$ dan Shafi et $\mathrm{al}^{8}$ dengan persentase $65,4 \%$ dan $52,2 \%$ pasien berjenis kelamin lakilaki. Hasil yang berbeda dilaporkan oleh Wilkins et $\mathrm{al}^{9}$ yang mendapatkan frekuensi penggunaan FOL lebih banyak pada perempuan $(71,4 \%)$.

terdapat beberapa indikasi penggunaan pemeriksaan FOL pada pasien. Pada penelitian ini indikasi paling sering ialah keluhan disfonia yang didapatkan sebanyak $80 \%$. Hasil ini serupa dengan yang didapatkan oleh Shafi et $\mathrm{al}^{8}$ dan Aljuboori $^{10}$ yang mendapatkan $50,6 \%$ dan $51,5 \%$ pasien melakukan pemeriksaan FOL dengan indikasi disfonia. Disfonia merupa- kan setiap gangguan suara yang disebabkan oleh kelainan pada organ-organ fonasi terutama laring. ${ }^{11}$ Selain disfonia, indikasi pemeriksaan FOL yang didapatkan pada penelitian ini ialah batuk darah $(10 \%)$ dan disfagia (10\%). Indikasi batuk darah ini dilakukan pada pasien yang dicurigai mengalami TB relaps.

Dari hasil pemeriksaan FOL, pasien paling sering didiagnosis dengan disfonia akibat obstruksi (60\%). Hasil ini sejalan dengan yang ditemukan oleh penelitian Shafi et $\mathrm{al}^{8}$ tetapi ini tidak sejalan dengan penelitian oleh Wilkins et $\mathrm{al}^{9}$ dimana diagnosis terbanyak ialah laringofaringeal refluks (LPR) sebanyak 42,5\%. Selain akibat obstruksi, disfonia dapat disebabkan antara lain oleh radang, tumor, paralisis otot laring, kelainan laring seperti sikatriks akibat operasi, dan fiksasi pada sendi krikoaritenoid. $^{11}$

Pada penelitian ini didapatkan bebe- 
rapa gambaran patologik dari hasil pemeriksaan FOL. Gambaran patologik yang paling sering ialah aritenoid yang edema $(35,71 \%)$ dan hiperemis $(28,58 \%)$. Selain itu, didapatkan juga korda vokalis yang menebal $(7,14 \%)$. Iqbal et $\mathrm{al}^{7}$ juga melaporkan hasil yang serupa yaitu $7,1 \%$ pasien dengan korda vokalis yang menebal. Pada penelitian ini didapatkan juga paresis korda vokalis unilateral sebanyak $7,14 \%$. Hasil penelitian Shafi et $\mathrm{al}^{7}$ dan Iqbal et $\mathrm{al}^{8}$ juga mendapatkan paresis korda vokalis sebanyak $5 \%$ dan $13 \%$, dengan paresis unilateral terjadi pada $8,6 \%$ pasien.

Limitasi penelitian ini yaitu jumlah sampel yang sedikit dan data rekam medik yang tidak lengkap.

\section{SIMPULAN}

Berdasarkan hasil penelitian ini dapat disimpulkan bahwa pemeriksaan FOL digunakan untuk beberapa indikasi, dengan indikasi tersering yaitu disfonia. Gambaran patologik yang tersering ialah pada aritenoid berupa edema dan hiperemis.

\section{SARAN}

Perlu sampel dan data rekam medis yang lengkap, agar penelitian ini bisa lebih efektif dan optimal dalam pelaksanaan penelitian selanjutnya.

\section{DAFTAR PUSTAKA}

1. Collins SR. Direct and Indirect laryngoscopy: equipment and techniques. respiratory care. 2014;59(6):850-64.

2. Goldberg JE. Flexible fiberoptic laryngoscopy. [cited 2018 Aug 13]. Available from: https://www.jgoldbergmd.com/ flexible-fiberoptic-laryngoscopy.php

3. Yunizaf R, Zulka E, Tamin S, Surya G. Penggunaan esofagoskopi transnasal di rumah sakit Dr. Cipto Mangunkusumo. ORLI. 2017;47(1):65-73.

4. Athiyyah AF, Darma A, Ranuh R, Subijanto. Peran prosedur endoskopik dalam mendiagnosis gangguan pencernaan pada anak. Jurnal Ners. 2012; 7(2):153-60.

5. Samin S. Flexible evaluation of swallowing (FEES) pada anak. [cited 2018 Aug 28]. Available from: http://staff.ui.ac.id/ system/files/users/susyana.tamin/public ation/makalah-fees_pada_anak_1.pdf

6. Kaminang GA, Waleleng BJ, Polii EBI. Profil endoskopi gastrointestinal di RSUP Prof. Dr. R. D. Kandou Manado Manado periode Januari 2016-Agustus 2016. eCl. 2016;4(2).

7. Iqbal Z, Rabbani MZ, Zafar MJ. Flexible nasopharyngolaryngoscopy: diagnostic yield. Rawal Med J. 2009;34:148-50.

8. Shafi M, Shaikh AA, Ahmed J. Flexible fiberoptic nasopharyngolaryngoscopy: indications and outcome. Journal of Surgery Pakistan. 2015; 20(2):56-9.

9. Wilkins T, gillies RA, Getz A, Zimmerman D, Kang L. Nasolaryngoscopy in a family medicine clinic. J Am Board Fam Med. 2010;23:591-7.

10. Al-juboori AN. The role of nasolaryngoscopy in the management of persistent throat symptoms in Fallujah City, Iraq. Br J Sci. 2012;6:22-7.

11. Hermani B, Hutauruk SM. Disfonia. In: Soepardi AA, Iskandar N, Bashiruddin J, Restuti RD, editors. Buku Ajar Ilmu Kesehatan Telinga Hidung Tenggorok Kepala Leher (7th ed). Jakarta: FK UI, 2012; p. 209-12. 